Portland State University

PDXScholar

7-5-1995

\title{
The Chemotactic Response of Neutrophils to Components of the Sera of Mice Infected with Trichinella spiralis
}

Sara Lynn Youngman

Portland State University

Follow this and additional works at: https://pdxscholar.library.pdx.edu/open_access_etds

Part of the Biology Commons

Let us know how access to this document benefits you.

\section{Recommended Citation}

Youngman, Sara Lynn, "The Chemotactic Response of Neutrophils to Components of the Sera of Mice Infected with Trichinella spiralis" (1995). Dissertations and Theses. Paper 5066.

https://doi.org/10.15760/etd.6942

This Thesis is brought to you for free and open access. It has been accepted for inclusion in Dissertations and Theses by an authorized administrator of PDXScholar. Please contact us if we can make this document more accessible: pdxscholar@pdx.edu. 


\section{THESIS APPROVAL}

The abstract and thesis of Sara Lynn Youngman for the Master of Science: Biology were presented July 5, 1995, and accepted by the thesis committee and the office of graduate studies.

COMMITTEE APPROVALS:

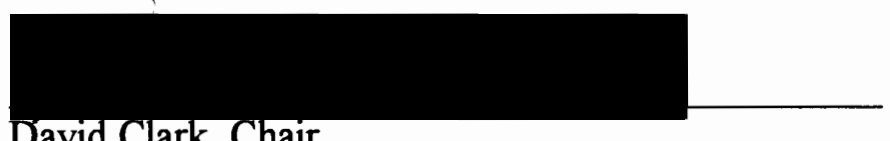

David Clark, Chair

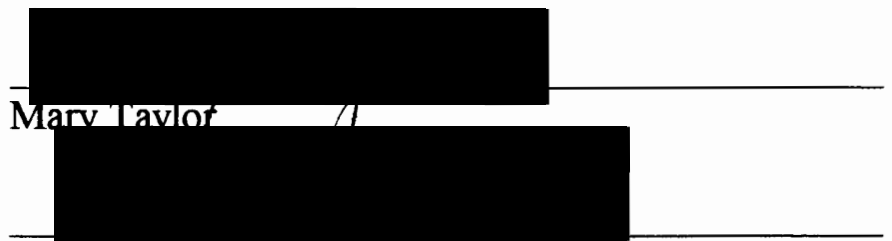

Randv Zelick o 0

Ansel Johnson

Office of Graduate Studies Representative

Leonard Simpson, Chair

Department of Biology

\section{ACCEPTED FOR PORTLAND STATE UNIVERSITY BY THE LIBRARY}

by

on 31 Auquat 1995 


\begin{abstract}
An abstract of the thesis of Sara Lynn Youngman for the Master of Science: Biology presented July 5, 1995.

Title: The Chemotactic Response of Neutrophils to Components of the Sera of Mice Infected with Trichinella spiralis.
\end{abstract}

Neutrophils accumulate around Trichinella spiralis larvae encysted in skeletal muscle cells of the host. The magnitude of the neutrophil infiltration follows a pattern relating to the stage of infection of T.spiralis. This study was performed to determine if there are factors chemotactic for neutrophils present in the sera of mice infected with T.spiralis, and if present, to compare the chemotactic potential of sera from several time points during the infection. Female MRL++ mice hosted the T.spiralis infection and provided neutrophils for all experiments. The chemotactic potentials of sera were tested by placing $150 u$ of serum collected at zero, four, 11 , or 28 days following initial infection of the mouse with T.spiralis, into the bottom well of a modified Boyden chamber called a deep well chemotaxis chamber. Next a PVP-free polycarbonate micropore membrane with a pore size of $5 u \mathrm{~m}$ was placed over the bottom well. The top chamber was then fastened to the bottom well and filled with a neutrophil suspension which was obtained by gradient layer centrifugation using the NIM $\bullet 2$ step gradient reagent system. A cover glass was placed over the opening of the top well and the entire apparatus was incubated at 
$37^{\circ} \mathrm{C}$ under $5 \% \mathrm{CO}_{2}$ in a humidified incubator for four hours. Following the incubation cells which had migrated through to the bottom well were counted using a hemocytometer and the membranes were stained with Diff Quick. The results demonstrate that there are factors present in the sera of mice infected with T.spiralis that elicit the chemotactic response of neutrophils in vivo. This work also demonstrates that sera from mice infected 11 and 28 days are significantly more chemotactic for neutrophils than are sera from uninfected mice and mice infected four days. These findings correlated with the histologic appearance of the infected skeletal muscle at four, 11 and 28 days post infection as determined by other members of our laboratory. The chemokines $\mathrm{IL}-8$ and $\mathrm{KC}$, and other chemotactic factors such as $\mathrm{C} 5 \mathrm{a}$ are discussed as potential mediators of the neutrophil chemotaxis found in this experiment. 
THE CHEMOTACTIC RESPONSE OF NEUTROPHILS TO COMPONENTS OF THE

SERA OF MICE INFECTED WITH TRICHINELLA SPIRALIS

by

SARA LYNN YOUNGMAN

A thesis submitted in partial fulfilment of the requirements for the degree of

MASTER OF SCIENCE

in

BIOLOGY

Portland State University

1995 


\section{TABLE OF CONTENTS}

PAGE

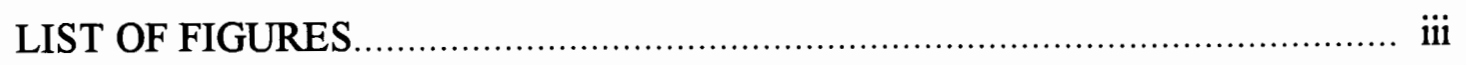

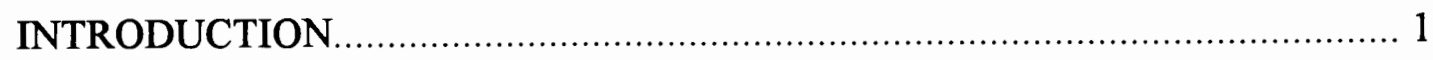

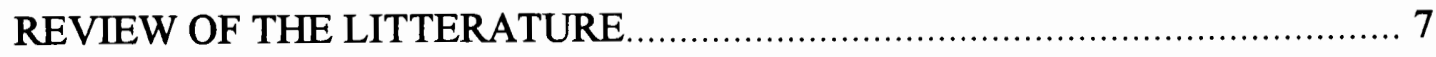

The Classical Chemoattractants.................................................. 7

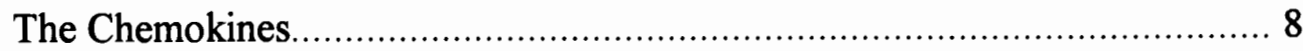

Adhesion Molecules, Cytokines, and Chemotaxis............................ 10

The Life Cycle of Trichinella spiralis....................................... 11

Measurement of Lymphocyte Chemotaxis.................................... 15

MATERIALS AND METHODS ........................................................... 17

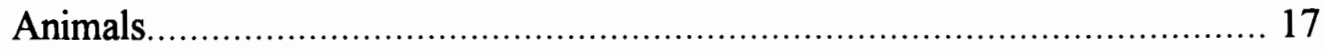

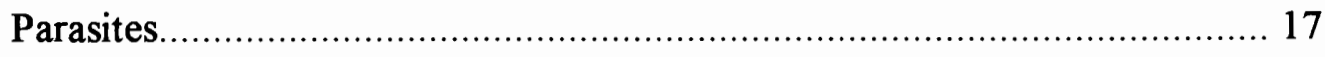

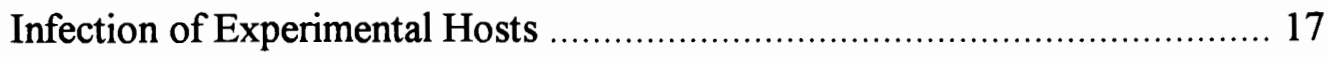

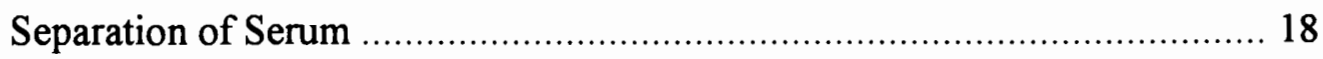

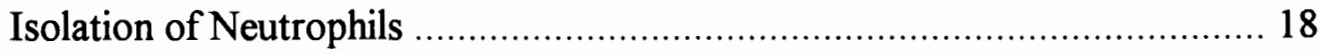

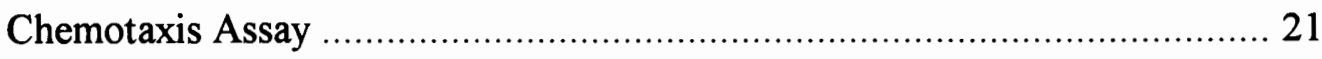




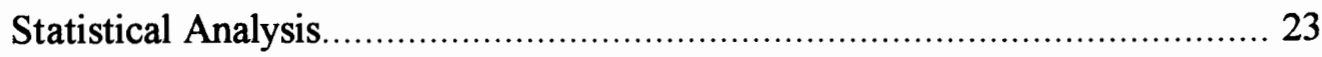

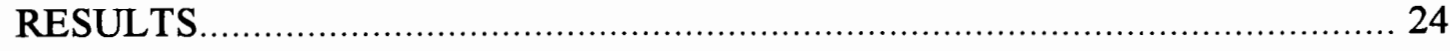

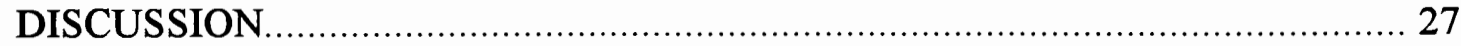

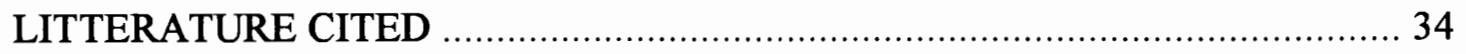




\section{LIST OF FIGURES}

FIGURE

PAGE

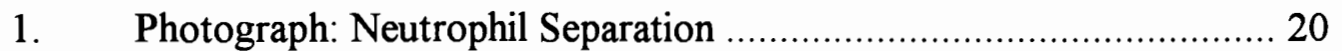

2. Line Drawing: Neutrophil Separation .......................................... 20

3. Chemotactic Chamber Components .............................................. 22

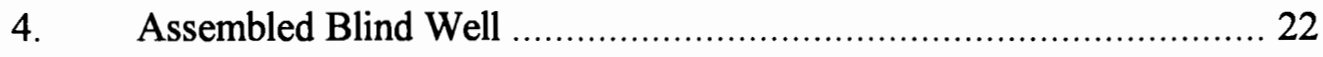

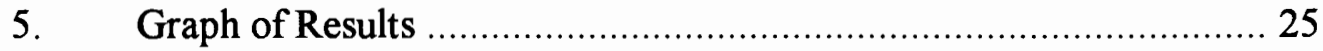

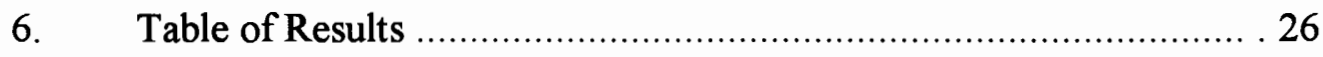




\section{INTRODUCTION}

Leukocytes are the first line of defense against many pathogens, including bacteria, fungi and parasites. Leukocytes are also effective in phagocytosing tumor cells. The neutrophil is the most numerous of leukocytes in the blood and normally constitutes $50-70 \%$ of the total. However, during pathogenic conditions such as bacterial infections, their number in the circulatory system can increase dramatically. This increased number of circulating neutrophils is called leukocytosis (Palmblad, 1984).

Elevated numbers of neutrophils have been observed within the affected tissues in many inflammatory diseases such as the synovial joints in patients with rheumatoid arthritis (Brennan et al, 1990), the mesothelium of patients with peritonitis (Zeillemaker et al, 1995), and the lesions of ulcerative colitis and Crohn's disease (Rizzo et al, 1992, Mitsuyama et al, 1994). Elevated numbers of neutrophils have also been observed surrounding the infective larvae of Trichinella spiralis in the muscle tissue of infected mice and rats (Prulhiere, 1994).

Neutrophil migration, or the chemotactic response of the neutrophil, is directed by the presence of chemokines. The chemokines are secreted by selected cells in association with the pathogenic agent. If a sufficient number of neutrophils migrate to the site, 
inflammation may occur, which is a crucial feature of host defense against invading organisms. Failure of migration, such as that due to specific granule deficiency within the neutrophils (Gallin, 1985) is associated with a marked increase in life threatening infections (Gallin, 1981).

Cytokines are polypeptides secreted by cells of the immune system and by other cells that provide accessory and/or modulatory functions for the immune system. Cytokines are like hormones, but usually they are produced transiently and act locally. They may also be transported through the bloodstream and lymphatics to act on target cells, cells expressing specific receptors, at distant sites. Cytokines are extremely potent, acting at picomolar concentrations, and they may be regulated by degradation or neutralization. Because they are effective at such low concentrations, they may form a gradient to which target cells orient and migrate (Miller and Krangel, 1992).

The migration of circulating neutrophils into a site of pathogenic activity, usually occurs in response to a positive gradient of cytokines or other chemotactic substances. Several chemotactic factors which differ in chemical structure, origin, and receptor specificity induce neutrophil migration. Bacterial-formylated peptides, $\mathrm{MLPs}$, have been said to play a critical role in neutrophil recruitment at inflammatory sites in several infectious diseases (Fontan et al, 1992). Leukotriene $\mathrm{B}_{4}\left(\mathrm{LTB}_{4}\right)$ is secreted by several types of cells and is known to activate and elicit chemotaxis primarily of neutrophils (Michel et al, 1987). Neutrophils, endothelial cells and a variety of other cells produce platelet activating factor (PAF); this cytokine is known to be chemotactic for neutrophils (Goetzl and Pickett, 1980). Complement-derived chemoattractant C5a attracts monocytes and 
neutrophils which are the only cell types known to express C5a receptors (Kelner et al, 1994). Tumor necrosis factors alpha and beta (TNF $\alpha, T N F \beta)$, cytokines secreted by macrophages and T-cells, are known to cause chemotaxis, priming, and degranulation of neutrophils (Livingston et al, 1989, Newman et al, 1989, Richter et al, 1989). Interleuken-8 (IL-8) is secreted by monocytes, T-cells, endothelial cells, fibroblasts, keratinocytes, and chondrocytes. It is also known to cause chemotaxis, priming, and degranulation of neutrophils (Matsushima and Oppenheim, 1989, Schroeder et al, 1990, Djeu et al, 1990).

Prulhier's work (1994) clearly demonstrated that neutrophils infiltrate the muscle tissue of mice infected with $T$. spiralis, that this infiltrate develops over the course of infection, and that these cells locate to the poles of the muscle cells which contain encysted larvae. Although it is known that neutrophils accumulate in the muscle tissue infected with $T$. spiralis, it is not known what function they serve there or by what means they are recruited to the site. The present study demonstrates that the factors responsible for neutrophil recruitment are present in the sera of infected mice, and that these factors are capable of eliciting the chemotactic response of neutrophils.

Because the accumulation of neutrophils develops during the infective process of T. spiralis larvae, the current work attempts to correlate the level of in vitro chemotactic response of neutrophils with serum components present at certain time points in the development of $T$. spiralis infection. The current work also attempts to demonstrate that the magnitude of the chemotactic response elicited by the serum components correlates with the stage of infection and also the number of neutrophils present at the pathogenic 
site demonstrated by Prulhiere (1994).

Because the infiltrate is predominantly neutrophils, and not monocytes, macrophages, or leukocytes, the chemokine(s) responsible must be those that are specifically chemotactic for neutrophils. The chemotactic factors mentioned above, $\mathrm{LTB}_{4}$, C5a, TNF $\alpha, \operatorname{TNF} \beta$, and $\mathrm{IL}-8$, are possible candidates. Receptors for each of these chemotactic factors have been identified on human neutrophils (Samanta, 1989). In a study comparing $I L-8, C 5 a, I L-1 \beta$, and TNF $\alpha$ in vitro, $I L-8$ and $C 5 a$ were found to be the strongest chemoattractants for blood neutrophils, while no response was observed toward IL-1 $\beta$, or TNF $\alpha$ (Persson, 1993). In another study the in vitro response of neutrophils to IL-8, $\mathrm{LTB}_{4}$, and PAF were compared in a dose-response manner (Thomsen, 1991); all three cytokines attracted neutrophils in a dose-dependent manner; the maximal chemotactic response of neutrophils towards IL-8 was found to be significantly greater than the response elicited by $\mathrm{LTB}_{4}$ or PAF. Another study which compared the in vitro chemotactic response of neutrophils towards $\mathrm{LTB}_{4}, \mathrm{C} 5 \mathrm{a}, \mathrm{PAF}$, and fMLP found that the chemotactic response to $\mathrm{LTB}_{4}$ was by far the greatest (Strom, 1990). Taken together these data indicate that IL-8 is the most potent of the cytokines for neutrophil chemotaxis.

The correlation between IL-8 concentration and number of infiltrating neutrophils has been demonstrated for several different experimental pathologies. Following the injection of recombinant IL-8 into rat peritoneal cavities, a dose-dependent neutrophil migration was observed (Ribeiro et al, 1991).

Tsuchiya et al (1993) found a good correlation between IL-8 levels and neutrophil chemotactic response after OK-432, a well-known streptococcal preparation for an anti- 
tumor drug, was administered into the pleural cavity of patients with malignant pleurisy. And confirming that $\mathrm{L}-8$ and $\mathrm{C} 5 \mathrm{a}$ are mostly responsible for the neutrophil chemotaxis in the pleural fluids, they showed that sequential masking of IL-8 and C5a abrogated totally $80 \%$ of chemotaxis.

An exogenous gradient of IL-8 induces neutrophil trans migration across nonactivated endothelium (Smith et al, 1991), and endothelium activated by $\mathrm{IL}-1$ or TNF $\alpha$ induces the transendothelial migration of neutrophils (Furie and McHugh, 1989).

Preincubation of neutrophils with $\mathrm{IL}-8$ reduces their chemotactic transmigration response to an $\mathrm{IL}-8$ gradient by $81 \%$, and transmigration due to activated endothelium is reduced by $104 \%$ after IL-8 preincubation (Smith et al, 1993).

In a study of human beings afflicted with inflammatory bowel disease (Mitsuyama et al, 1994), the colonic mucosa was found to contain high levels of $\mathrm{IL}-8$ in patients with active disease and low levels were found in patients with inactive disease; the levels correlated significantly with the grade of local inflammation and the number of neutrophils present in the mucosal tissue. Colonic $\mathrm{IL}-1 \beta$ and $\mathrm{TNF} \alpha$ were also correlated with the degree of inflammation in these tissues suggesting their involvement in neutrophil migration in inflammatory bowel disease.

Although an IL-8 homologue has not been described in the mouse, a rodent interleuken related cytokine has been described. This protein is named " $\mathrm{KC}$ ", some authors use "gro". The protein has been implicated in many of the rodent equivalent pathologies in which $\Pi$-8 is involved in humans (Shiratori et al, 1994). Recombinant rat $\mathrm{KC}$ (rKC) has been functionally characterized in vitro and in vivo (Frevert et al, 1995). In 
vitro, $\mathrm{rKC}$ induced neutrophil chemotaxis and increased the expression of CD11b/CD18, an adhesion molecule complex, on neutrophils. Intratracheal instillation of $\mathrm{rKC}$ induced dose-dependent neutrophil influx into the airspaces in rat models of lung injury.

In most inflammatory situations it is likely that there is more than one chemoattractant responsible for neutrophil infiltration. These chemoattractants may act in concert to achieve neutrophil recruitment to the site of pathogenic activity. A likely scenario, suggested by Smith (1993) is that initial stimulation by a pathogenic agent causes an increased production and/or release of $\mathrm{C} 5 \mathrm{a}$ and $\mathrm{TNF} \alpha$, which in turn causes an increased production and release of IL-8 which elicits neutrophil recruitment. 


\section{LITTERATURE REVIEW}

\section{The classical chemoattractants}

The "classical" chemoattractants, so called because their properties were elucidated relatively early, include $\mathrm{N}$-formyl-methionyl-leucyl-phenylalanine (AMLF), C5a, leukotriene $\mathrm{B}_{4}$, and platelet-activating factor (PAF). High affinity G-protein-coupled receptors have been identified for these proteins, as reviewed by Hwang (1990) and Haribabu and Snyderman (1993).

First reported by Shiffman et al in 1977 were a series of $\mathrm{N}$-formylmethionyl peptides, especially N-formylmethionyl-leucyl-phenylalanine (fMLP), that were chemoattractive for neutrophils. Years later these peptides were isolated from liquid cultures of bacteria and characterized (Harvath, 1991).

C5a is a small $(11-\mathrm{kDa})$, glycosylated, cationic peptide derived from the amino terminal end of the C5 alpha chain (Persson et al, 1993). This peptide is produced through activation of both the classic and the alternative complement pathways. The complement system, complement receptors and their involvement in disease were recently reviewed by Ashgar (1995). Human neutrophils express C5a receptors on their plasma membranes which consist of a single glycoprotein $(50 \mathrm{kD})$ coupled to a guanine nucleotide 
binding protein (Siciliano et al 1990).

Leukotriene $\mathrm{B}_{4}, \mathrm{LTB}_{4}$, is a product of the 5-lipoxygenase pathway of arachidonic acid. Although $\mathrm{LTB}_{4}$ is secreted by several types of cells, it is a major product of mast cells. Neutrophils can also produce substantial amounts of $\mathrm{LTB}_{4}$ when incubated with IL8 (Thomsen et al, 1991). Leukotriene $B_{4}$ is known to attract primarily neutrophils in vivo (Michel et al, 1987).

Like other classical chemoattractants, the phospholipid PAF (1-O-alkyl-2-acetylsn-glyceryl-3-phosphorylcholine) is a chemoattractant and activating factor for phagocytes and is also an anaphylatoxin (Hwang, 1990). It is known to activate and chemoattract neutrophils, but to a lesser extent than many of the other cytokines (Strom and Thomsen, 1990).

The chemokines

The name "chemokine" was proposed at the Third International Symposium of Chemotactic Cytokines at Baden in 1992, to convey the combined chemoattractant and cytokine properties that have been identified for many of these peptides. In contrast to the classical chemoattractants and most other cytokines, chemokines have remarkably conserved amino acid sequences, indicating that they arose from a common ancestral gene. The biology and biochemistry of the chemokines are reviewed in: Miller and Krangel (1992), Baggiolini (1993), and Kunkel et al (1994). The chemokines are a large superfamily of structurally and functionally related proteins that function in the recruitment and activation of leukocytes and other cells at cites of inflammation; therefore they appear 
to be important inflammatory mediators. These molecules are all small, secreted proteins which contain four cysteine residues arranged in one of two patterns: $\mathrm{C}-\mathrm{X}-\mathrm{C}$ or $\mathrm{C}-\mathrm{C}$.

The C-X-C family, also called $\alpha$ chemokines, contains the cytokines platelet factor 4, platelet basic protein, $\gamma$ IP-10, gro/MGSA, IL-8 (formerly called NAP-1 for neutrophil activating protein), mig, and ENA-78. The members of this family which have been mapped are mapped to human chromosome $4(q 12 \rightarrow q 21)$ and to mouse chromosome 5 (Kelner et al, 1994). In addition to their shared cysteine residue structure, the C-X-C chemotactic factors also share a common amino acid motif, ELR (glutamic acid, leucine, and arginine), which is present in juxtaposition to the first $\mathrm{NH}_{2}$-terminal amino acid of the C-X-C chain (Matsushima and Oppenheim, 1989). The importance of ELR is that this sequence is responsible for neutrophil activation via receptor ligand interactions. There are some members of the C-X-C family which do not possess the ELR motif and they are not chemotactic for neutrophils.

The C-C family, also called $\beta$ chemokines, contains the cytokines MIP-1 $\alpha$, MIP$1 \beta, \mathrm{I}-309, \mathrm{JE} / \mathrm{MCP}-1, \mathrm{MCP}-2, \mathrm{MCP}-3, \mathrm{RANTES}, \mathrm{C} 10$, and HC14. The members of this family which have been mapped are mapped to human chromosome $17(q 11 \rightarrow q 21)$ and to mouse chromosome 11 (Kelner et al, 1994). Recent data suggest that the ligand:receptor system for the C-C family is similar to the C-X-C system, but since this family is chemotactic predominantly for monocytes macrophages and lymphocytes (Miller and Krangel, 1992, Kelner et al, 1994) and not for neutrophils, some difference must exist. Most of the cytokines of both the C-X-C family and the C-C families have been defined in both humans and mice; exceptions are IL-8 and ENA-78, which have been 
found only in humans, and mig and C-10, which have been found only in mice (Miller and Krangel, 1992).

The extracellular matrix and its effect on the regulation of cytokines is reviewed by Lortat-Jacob and Grimaud (Lortat-Jacob and Grimaud, 1994). It has been determined that several chemokines are contained in the extracellular matrix while in an inactive state. Upon appropriate stimulation, the chemokines may be altered into their active state for serving their function. Active chemokines can also be held in place by components of the extracellular matrix thereby prolonging and localizing the effects of these chemokines.

\section{Adhesion Molecules, Cytokines, and Chemotaxis}

As reviewed by Bittleman and Casale (1994), Carlos and Harlan (1994), and Rosales and Juliano (1995) adhesion molecules are involved in neutrophil chemotaxis. The interactions between cytokines and the endothelial and epithelial cell barriers through which neutrophils must migrate may in part depend upon adhesion molecules expressed on the cells involved. There are a number of adhesion molecules expressed on the luminal surface of endothelial and epithelial cells that are important in neutrophil adhesion and transmigration. They include intercellular adhesion molecule 1 (ICAM-1), endothelialleukocyte adhesion molecule-1 (ELAM-1), granulocyte-associated membrane protein 140 (GMP-140/CD62). ICAM-1 is present on epithelial cells; TNF $\alpha$ and IL-1 have been shown to increase the cell surface expression of this molecule and support neutrophil adhesion to human epithelial cells. ICAM-1 and ELAM-1 are also found on endothelial cells; their cell surface expression is dependent on protein synthesis and upregulated by 
endotoxin, IL-1, TNF $\alpha$, and other cytokines. Antibodies against ICAM-1 and ELAM-1 have been shown to inhibit neutrophil adhesion to IL-1-stimulated endothelial cells. Unlike the other cytokines, GMP-140 is stored in endothelial cell granules and is released within five minutes of stimulation with mast cell mediators such as histamine. Once released from the granules, GMP-140 is rapidly moved to the cell surface where it mediates neutrophil adhesion. The molecules $\mathrm{LTB}_{4}$ and $\mathrm{IL}-8$ are capable of inducing endothelial cells to express GMP-140. $\mathrm{LTB}_{4}$ and $\mathrm{L}-8$ induce transendothelial migration; therefore, cytokines may induce inflammatory cell migration through epithelial and endothelial cell layers by inducing cell surface expression of adhesion molecules as well as being chemotactic for neutrophils.

\section{The Life Cycle of Trichinella spiralis}

In the infective process of Trichinella spiralis, the host, which can be most any mammal, but is usually a carnivore, becomes infected when it consumes larvae encysted in the skeletal muscle of an infected animal. The larvae are released from the cysts by the action of digestive enzymes in the stomach of the host. The larvae are transported by peristalsis to the upper two-thirds of the small intestine where they penetrate columnar epithelial cells and mature to the adult male and female forms of the nematode. The transit from release from cyst to penetration of intestinal cell can take as little as ten minutes (Despommier et al, 1978).

During a 30-hour period, the larvae grow and mature, undergo four molts, and become sexually mature male and female worms. Five days after copulation, the female 
begins to deposit live larvae which are $0.08 \mathrm{~mm}$ in length. The female continues producing larvae for 5-10 days, giving birth to approximately 1000 each day. In approximately 19 days, the adults are expelled by the host defense mechanisms responding to antigens in the worm. Besides the time from digestive release of the larvae to the initial infection in the host intestine, the only period of the $T$. spiralis life cycle spent extracellularly, is the migration of the new born larvae from the intestinal mucosae to the striated muscle. The migratory route has been studied but the exact manner in which the larva locates the skeletal muscle is not known.

Harley and Galliccho (1971) determined that the newborn larva penetrates the lamina propria of a villus using its stylet, and then moves into either the mesenteric lymphatics or the capillaries and then the blood stream. Those larvae that enter the lymphatic vessels arrive in the general circulation by way of the thoracic duct. All larvae eventually enter the general circulation and become distributed throughout the body of the host.

Wang and Bell (1986) studied the recirculation of the T. spiralis newborn larvae. These researchers injected newborn larvae into the tail vein or into the hepatic portal vein of mice and then took blood samples from the femoral vein, hepatic portal vein, and abdominal aorta at intervals from one minute to 24 hours following the injection. They found that larvae persisted in the femoral vein blood for less than five hours after injection and that the point of injection did not alter the pattern of migration. They did find evidence of transcapillary migration through tissue and the return back to the circulation. No evidence for trapping in the mesenteric lymph node was seen despite evidence of larval 
migration through this organ. Newborn larvae were retained in the lungs, and small numbers could be recovered 24 hours after injection. They concluded that a portion of the newborn larvae recirculate within the vasculature for several hours; however, a smaller portion extravate, but can reenter the circulatory system via the lymphatics.

To study the distribution of larvae following release, Bruschi et al (1992), injected radioactively-labeled larvae intravenously. It was found that the radioactivity was immediately retained in the lungs and was slowly released thereafter. At various times after the injection, the lungs were removed and parasites were inspected and counted. Fifty to seventy percent of the larvae were recovered after 30 seconds, and less than four percent at fifteen minutes. These results indicate that during the passage of larvae through the lungs, labeled components of the cuticle are detached and retained. The modifications produced in the cuticle of the newborn larvae during its passage through the lung may increase its resistance to the nonspecific defense mechanisms of the host.

Skeletal muscle cells are not destroyed by larval invasion. In fact, larva that enter skeletal muscle cells are able to stimulate the modification of their environment to support their growth and development. The modified muscle cell is called a nurse cell (Pukerson and Despommier, 1974) and is able to support the living larvae, supplying nutrients and removing wastes for many years. The nurse cell also provides an environment which generally protects the larvae from the host's immune system. The nurse cell phenotype could develop as a result of a normal muscle response to a persistent perturbation or by parasite factors affecting normal regulatory processes either directly or indirectly. Larvae that have penetrated tissues other than striated muscle fail to induce nurse cell formation 
and either reenter the capillaries or become surrounded by granulomas and eventually die.

Once the larva is inside the myocyte, morphologic changes take place and the cell becomes modified into a nurse cell. One change is that there is a marked decrease in myofibrillar proteins. Muscle-specific proteins alpha-actin, alpha- and beta-tropomyosin, and myosin heavy chain were found to be practically absent in nurse cells (Jasmer, 1990). Other organelles increase in number; these include mitochondria, lysosomes, smooth and rough endoplasmic reticulum, and Golgi apparatus. One of the earliest noted changes (Pagenstecher, 1865) in the development from muscle cell to nurse cell is the formation of vascular baskets that surround the nurse cells and provide the larvae with nourishment and waste removal. Baruch and Despommier (1991), performed a transcardial perfusion of plastic into the vasculature of $T$. spiralis-infected mice to characterize and photomicrograph the vascular casts formed around nurse cells. With the casts, Baruch demonstrated that the arborizing vascular baskets are found only around the parasitized nurse cells and are distinct from the blood supply to the remainder of the muscle. Her work confirmed an earlier assertion that the blood supply to a given basket may originate from more than one source (Humes and Akers, 1952). Baruch suggests that the baskets are produced de novo during $T$. spiralis infection and that the parasites may elicit angiogenesis directly through secretion of unique products or may elicit a change in the nurse cell that, in turn, results in growth of new blood vessels.

To determine the temporal relationship between synthesis and secretion of larval antigens while the T. spiralis larva is in the nurse cell, Despommier et al (1990), raised antibodies against a purified antigen (MW 43K) which is stage-specific for the infective Ll 
larvae of $T$. spiralis and is one of the secreted antigens from the larval stichosome. The antibody reacted with the stichosome and cuticle of mature larvae and the cytoplasm and nucleoplasm, but not the nucleolus of all nurse cells. Temporal studies revealed that the antigen was present only within the worm on the seventh day of infection. On the ninth day of infection the stichosome and cuticular surface of the larva and the cytoplasm and the nucleoplasm of each nucleus in the nurse cell reacted with antibody. Nurse cell cytoplasmic and nucleoplasmic reactivity to this antibody increased in intensity until 18 days after infection. These results suggest that this antigen is synthesized during the early phase of infection in the muscle, and that as the nurse cell/parasite complex develops, some of the antigen is secreted into the nurse cell. This implicates this antigen in the initiation or control of nurse cell formation.

\section{Measurement of Lymphocyte Chemotaxis}

The methods used to study chemotaxis have evolved over the last 80 years. First used were coverslips and slides, then capillary tubes and culture wells under agarose. The current preferred method involves the Boyden chamber or a modification of this apparatus. The Boyden chamber was first described by Boyden in 1962; the main advantage over previous methods is that the Boyden chamber allows quantification of the migrating cells because the system is closed. Since the advent of the Boyden chamber, researchers have been able to study the chemotactic ability of various cytokines alone or in combinations (Shupe and Stewart, 1991, Yano et al, 1995, Xu et al, 1995). The Boyden chamber consists of an upper and a lower well separated by a membrane filter with pore 
size too small for cells to diffuse through but small enough to allow migration of activated cells. Chemotactic solutions are placed in the lower well, cells are added to the top well. The apparatus is incubated for a period of time, then the cells which have migrated are counted. There are many modifications of this apparatus: a 48-well assembly (Falk et al, 1980) which is preferred for clinical use because of the smaller sample size needed and the minimization of manipulation involved, and a blind well version (Snyderman et al, 1972) which is preferred for its simplicity and its larger volume which allows a more accurate quantification. The membrane filter pore size may be selected to fit the particular cell type being quantified. Incubation times and conditions may be manipulated to fit the characteristics of the cell type and chemotactic factors involved. 


\section{MATERIALS AND METHODS}

\section{Animals}

Two-month-old-female MRL++ mice, originally obtained from Oregon Health Sciences University, Portland Oregon, and mainted as a breeding colony for 10 years, were used in all experimental protocols. All animals were housed at the Portland State University rodent facility where they received standard rodent chow and water ad libitum. Animals were maintained under the guidelines set forth by the joint Oregon Health Sciences University / Portland State University Animal Care Committee and the facility passed regular veterinary inspections.

\section{$\underline{\text { Parasites }}$}

Indiana bore strain of T.spiralis was obtained from Dr. Green, University of Missouri, Columbia. This strain was isolated and genetically characterized by Kazacos et al in Indiana (1986). It was maintained by passage through rats and mice.

\section{Infection of Experimental Hosts}

Mice were infected with $T$. Spiralis per os with enough meat to contain approximately 100 cysts. Infected tissue was obtained by removing the diaphragm and masseter muscle of a mouse infected for six months; six months is long enough to allow 
cyst formation around the larvae while not long enough to allow cyst calcification which can occur in very old infections and can prevent the larvae from being infectious. Tissues were examined under a dissecting microscope and divided into small pieces containing the appropriate amount of larvae in cysts. Experimental hosts were deprived of rodent chow for 12 hours, then placed in individual cages without bedding food or water. Mice were then given the appropriate amount of infected tissue which was kept moist with water until consumed. Each mouse was returned to its home cage once it had consumed the tissue $(0.5-6 h)$.

\section{Separation of Serum}

Fresh blood was collected by cardiac puncture using a three $\mathrm{ml}$ disposable syringe with a 21 gauge needle from uninfected mice or from mice four days, 11 days or 28 days following infection with 100 larvae of $T$. spiralis. From $0.5-1.0 \mathrm{ml}$ was obtained from each mouse. Blood samples were quickly placed in glass vacutainers containing $5.4 \mathrm{mg}$ $\operatorname{EDTA}\left(\mathrm{K}_{2}\right)$, an anticoagulant, inverted several times, and centrifuged 20 minutes in a swinging bucket rotor at 900-1000 g at room temperature. Serum samples were carefully removed using sterile Pasteur pipettes and immediately placed in a $-20^{\circ} \mathrm{C}$ freezer for storage until use.

\section{Isolation of Neutrophils}

A two component step gradient reagent system, NIM•2 (Cardinal Associates, Santa Fe, NM), was used to retrieve neutrophils from whole blood. Two $\mathrm{ml}$ of the lower 
gradient material (NIM•2A) was added to a 13 X $100 \mathrm{~mm}$ borosilicate glass culture tube. Two $\mathrm{ml}$ of the upper gradient $(\mathrm{NIM} \cdot 2 \mathrm{~B})$ was layered onto the lower gradient material. The tube was covered with Parafilm and brought to room temperature. Calcium/magnesium free HBSS, $0.5 \mathrm{ml}$, was added to five $\mathrm{ml} \operatorname{EDTA}\left(\mathrm{K}_{2}\right)$ vacutainer tubes and mixed. Fresh blood was collected via cardiac puncture as described above from two to five uninfected mice and pooled following mixture with EDTA. Anticoagulated mouse blood, $2.5 \mathrm{ml}$, was carefully layered onto the upper layer of each NIM•2 tube. Parafilm was applied to seal the tubes. The tubes were centrifuged in a swinging bucket rotor at $1000 \mathrm{~g}$ for 30 minutes at $16^{\circ} \mathrm{C}$. Following centrifugation, the plasma layer (see Fig. 1 for photograph and Fig. 2 for a diagram of the resulting gradient layers) was carefully removed and discarded. The neutrophil layer was removed by moving the Pasteur pipette tip through the remaining mononuclear cell band and upper NIM•2 band to the lower neutrophil band. This band was then gently pipetted out with the lower NIM•2 layer leaving the RBC pellet below. This mixture was placed in a fresh borosilicate tube containing five ml Modified (calcium and magnesium free) Hanks' Balanced Salt Solution (HBSS). This mixture was mixed well and centrifuged at $400 \mathrm{~g}$ for ten minutes. The supernatant was drawn off and discarded. The cells were resuspended with two $\mathrm{ml}$ of erythrocyte lysing buffer (RBC Lysis Buffer, Analytical Genetic Testing Center, Denver, $\mathrm{CO})$, then centrifuged at $400 \mathrm{~g}$ for ten minutes. The supernatant was drawn off and discarded. This was repeated until the supernatant was clear, usually four times. Neutrophils were then resuspended in $0.5 \mathrm{ml}$ RPMI 1640 media. Neutrophil concentration and viability were determined by mixing $100 \mu \mathrm{l}$ cell suspension with $20 \mu \mathrm{l}$ 


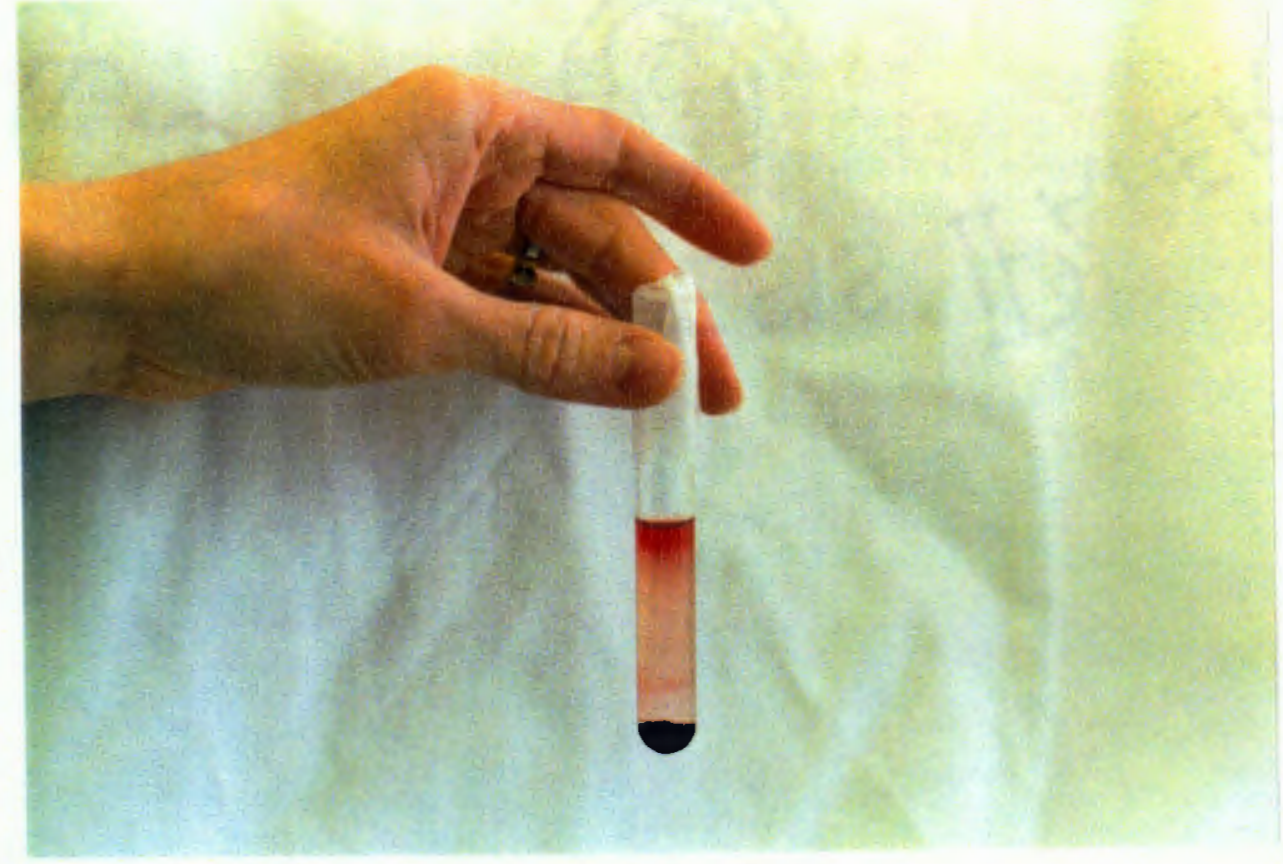

Figure 1. Gradient layer separation of mouse whole blood using the NIM:2 two component step gradient reagent system (Cardinal Associates, Santa Fe, NM)

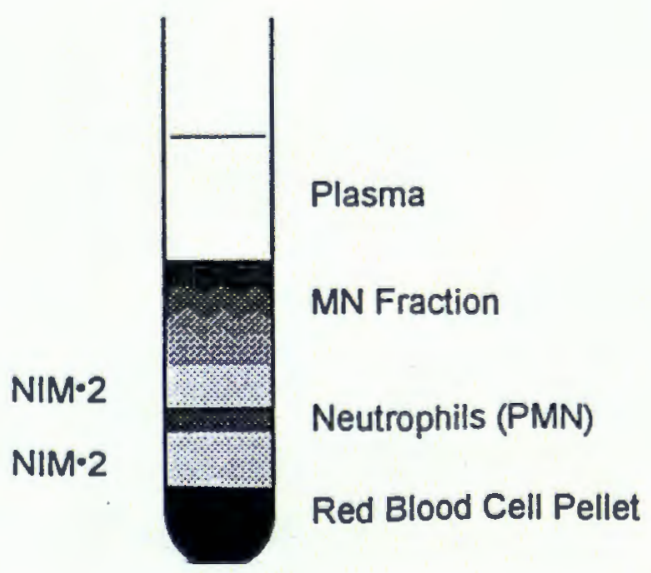

Figure 2. Line drawing of the gradient layer separation of mouse whole blood. Resulting blood component layers are labeled on the right side of the tube. Layers of NIM.2 separate the neutrophil layer from the other components of whole blood. 
trypan blue and counting live (translucent) and dead (blue) cells using a hemacytometer and a compound microscope with a $40 \times$ objective. At this point it was also possible to determine, by cell morphology, if the cell suspension contained cell types other than neutrophils. The concentration was then adjusted to approximately $64 \times 10^{6} \mathrm{cells} / \mathrm{ml}$.

\section{Chemotaxis Assay}

Neutrophil chemotactic activity was measured in single blind well chemotaxis chambers (Neuro Probe, Cabin John, MD; see Fig. 3 for a photograph of the blind well components). The bottom wells were filled with $150 \mu \mathrm{l}$ of serum from mice infected with Trichinella spiralis collected four, 11 , or 28 days following the initial infection, serum from uninfected mice, lipopolysaccharide (LPS), or RPMI 1640 medium. Polyvinylpyrrolidone (PVP)-free polycarbonate micropore filter sheets (Poretics Corp., Livermore, CA) with a pore size of $5 \mu \mathrm{m}$ were placed over the bottom wells, shiny-side up, with forceps. The top wells were fastened to the bottom wells and the neutrophil suspension, $250 \mu \mathrm{l}$, was added to each top well. Cover glass was placed on each assembly (see Fig. 4 for a photograph of the assembled well). Blind well assemblies were incubated for four hours at $37{ }^{\circ} \mathrm{C}$ in humidified air with $5 \% \mathrm{CO}_{2}$. Following incubation, cell suspensions were carefully removed from the top chambers by means of an automatic pipet and discarded. The membrane was carefully removed with forceps, fixed in methanol, stained with DiffQuick (Harlew, Gibbstown, NJ), and mounted with 


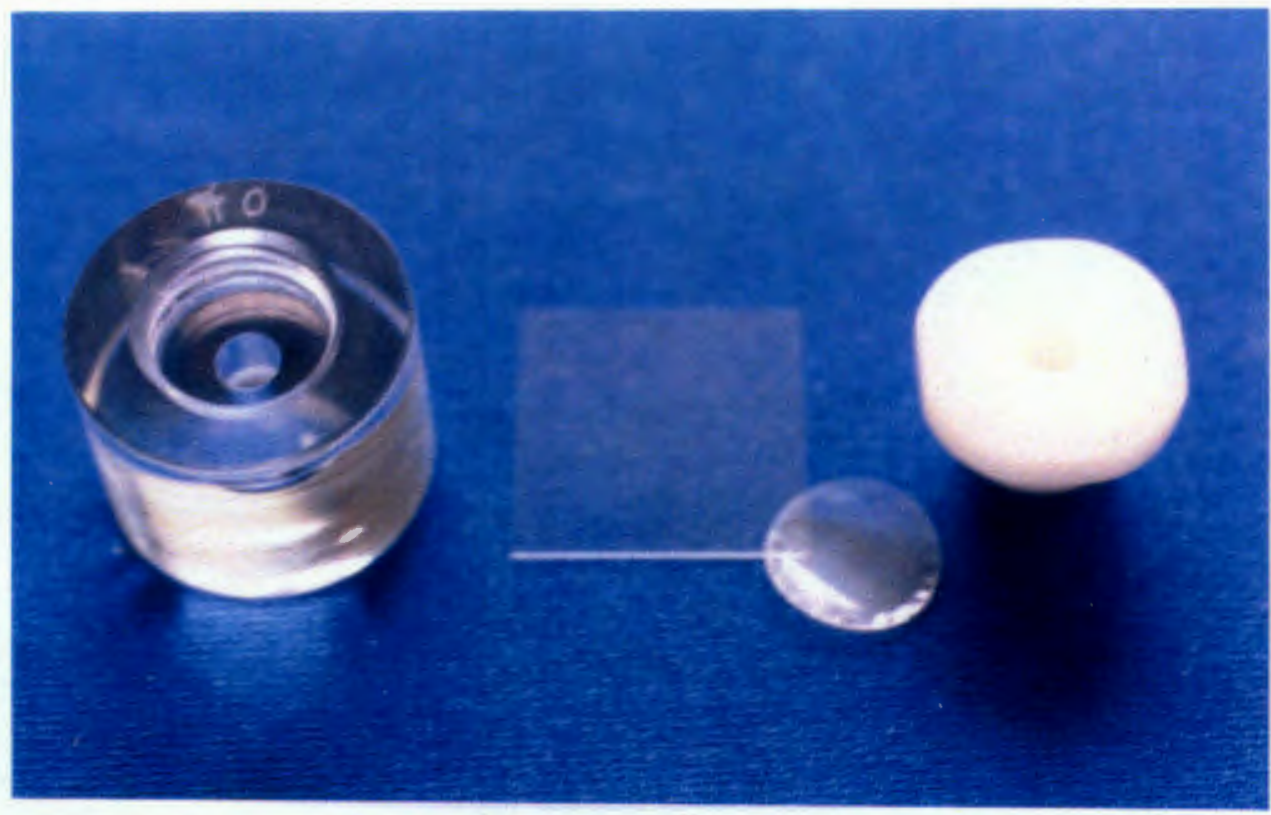

Figure 3. Components of the blind well chemotactic chamber assembly (Neuro Probe, Cabin John, MD) used to measure the chemotactic response of neutrophils to sera of mice infected with Trichinella spiralis. From left to right: bottom well, cover glass, micropore filter sheet (Poretics Corp., Livermore, CA), top well.

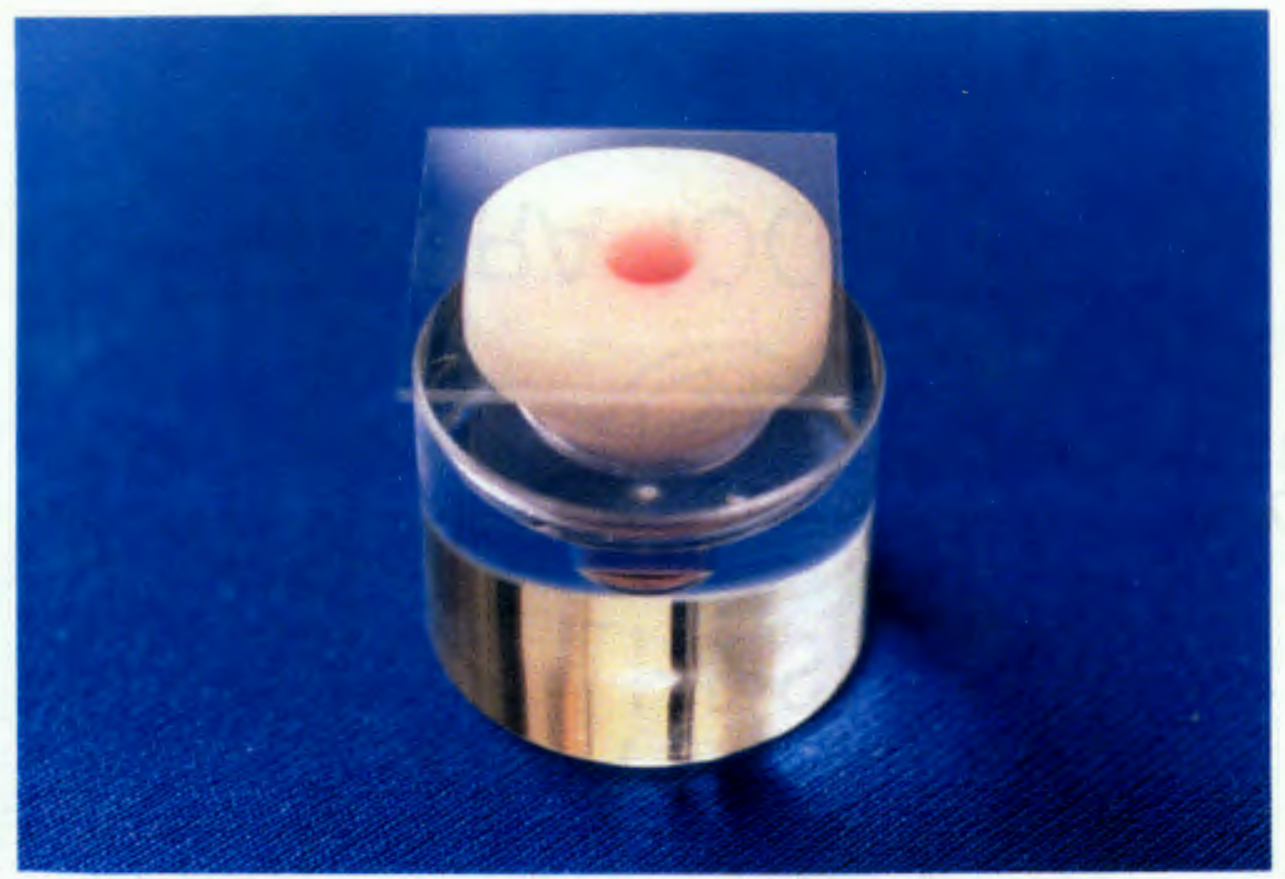

Figure 4. Assembled blind well chemotactic chamber (Neuro Probe, Cabin John, MD) as prepared for incubation. 
Immumount (Shandon, Pittsburgh, PA) bottom-side up on a glass slide. Cells which had migrated completely through the membrane to the serum in the bottom well chamber were vigorously suspended with an automatic pipet; $100 \mu \mathrm{l}$ were added to $20 \mu$ l of trypan blue solution. The number and viability of the cells in the bottom chamber were determined using a hemocytometer; three random counts were made per well, and averaged for each bottom well component tested. A total of 27 deep well tests were made: five testing serum from five uninfected mice, five testing serum from five mice four days following infection with T.spiralis, five testing serum from five mice $11 \mathrm{~d}$ post-infection, five testing serum from five mice $28 \mathrm{~d}$ post-infection, and five using RPMI 1640 medium as a control for random migration, and 2 tested LPS $(250 \mu \mathrm{g} / \mathrm{ml})$; these were run in four sets, with a maximum of nine wells incubated at one time.

\section{$\underline{\text { Statistical Analysis }}$}

The neutrophil concentration present in the sera or media of the bottom wells following incubation were compared for each group ( $n=$ five per group) by a one way analysis of variance using a computerized statistical program (Primer of Biostatistics: The Program, Stanton A. Glantz, McGraw-Hill Company, NY). A post hoc comparison between groups was made using the t-test at the $95 \%$ confidence interval to compare the equality of the means. 


\section{RESULTS}

The results are diagrammed in Fig. 5; raw data are presented in Fig. 6. Groups which were significantly different $(\mathrm{P}<0.001)$ from RPMI 1640 medium, are marked with an asterisk. The serum from uninfected mice, control serum, was not significantly $(\mathrm{P}=0.268)$ more chemotactic than the RPMI 1640 medium. The serum from mice infected

four days (Day 4) was not significantly more chemotactic than control serum $(P=0.681)$ serum from Day 11 was significantly more chemotactic than Day $4(\mathrm{P}<0.001)$, and Day 28 serum was significantly more chemotactic than Day 11 serum $(\mathrm{P}=0.084)$. LPS was not found to be significantly more chemotactic for neutrophils than serum alone $(\mathrm{P}=0.626)$. Examination of the stained microfilters showed that no cells were adherent. It was also apparent that the microfilters were completely intact following the experiment. 


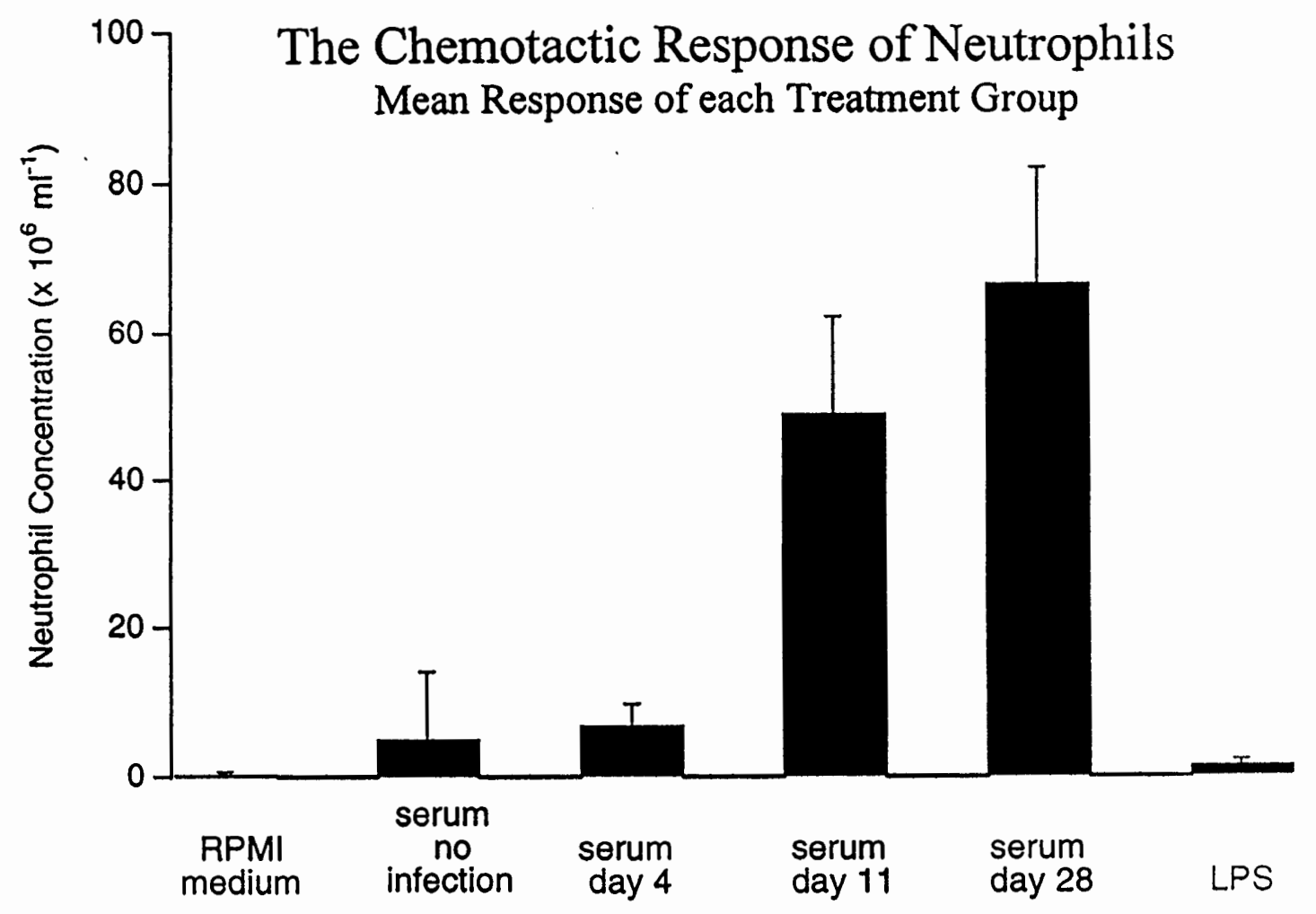

Treatment Group

Figure 5. Chemotactic response of neutrophils in response to serum, LPS, and RPMI 1640 medium. Diagramed are the mean number of cells for the group tested (LPS $n=2$, all other groups $n=5$ ) in millions of neutrophils $/ \mathrm{ml}$. The treatment groups, from left to right, are: RPMI medium, serum from uninfected mice, serum from mice infected $4 \mathrm{~d}$ with T.spiralis, serum from mice infected $11 \mathrm{~d}$ with T.spiralis, serum from mice infected $28 \mathrm{~d}$ with T.spiralis, and lipopolysaccharide, $250 \mu \mathrm{g} / \mathrm{ml}$ (LPS). The standard error of the mean (SEM) for each treatment group is shown with an error bar. 


\begin{tabular}{|c|c|c|c|c|c|}
\hline \multicolumn{6}{|c|}{ RESULTS } \\
\hline \multicolumn{6}{|c|}{ Treatment groups } \\
\hline $\begin{array}{l}\text { Low control } \\
\text { (RPMI) }\end{array}$ & $\begin{array}{c}\text { Day 0 } \\
\text { serum } \\
\text { no infection }\end{array}$ & $\begin{array}{l}\text { Day } 4 \\
\text { serum }\end{array}$ & $\begin{array}{l}\text { Day } 11 \\
\text { serum }\end{array}$ & $\begin{array}{l}\text { Day } 28 \\
\text { serum }\end{array}$ & LPS \\
\hline 5 samples & 5 animals & 5 animals & 5 animals & 5 animals & 2 samples \\
\hline \multicolumn{6}{|c|}{ Raw Data } \\
\hline 0 & 0 & 6 & 54 & 48 & 1 \\
\hline 0 & 21 & 11 & 38 & 61 & 2 \\
\hline 0 & 2 & 7 & 68 & 90 & \\
\hline 0 & 0 & 3 & 50 & 68 & \\
\hline 0 & 2 & 7 & 35 & 67 & \\
\hline & & standard & tion (SD) & & \\
\hline 0.2 & 5 & 6.8 & 49 & 66.8 & 1.5 \\
\hline 0.45 & 9 & 2.86 & 13.27 & 15.22 & 0.7 \\
\hline 0.2 & 4.02 & 1.28 & 5.93 & 6.81 & 0.5 \\
\hline
\end{tabular}

Figure 6. Table of results and statistical analyses. The raw data are counts of neutrophils in millions of cells per ml solution contained in the bottom well of each chemotactic chamber following incubation. The mean, standard deviation, and standard error of the mean are calculated for each treatment group. 


\section{DISCUSSION}

The current work demonstrates that there are factors present in the sera of mice infected with T.spiralis that elicit the chemotactic response of neutrophils in vivo. This work also demonstrates that the sera from mice infected 11 and 28 days are significantly more chemotactic for neutrophils than sera from uninfected mice and mice infected four days. These findings correlate with the immunohistochemical evidence obtained by Prulhiere (1994): at four days post infection there were no larvae or neutrophils present in the diaphragm; at 11 days post infection larvae were beginning to invade the tissue and a very few neutrophils were present; at 20 days post infection, the last time point studied by

Prulhiere, the diaphragm showed greater than 50 encysted larvae and a heavy neutrophil accumulation.

Because neutrophils are the first line of defense against many pathogens, one could postulate that during the infective process when the larvae reach the muscle tissue, some event such as cellular damage from the larvae burrowing through myocytes, or the presence of larval excretory/secretory fluids, may initiate a chain of events which result in the attraction of neutrophils to the site of pathogenic activity. This process may involve the formation of C5a (Smith et al, 1993), which would stimulate resident cells to produce and release an $\mathrm{IL}-8$ like protein, $\mathrm{KC}$, which would then form a concentration gradient that 
would serve as a chemoattract for the attraction of neutrophils to the larval site.

Complement may be involved in neutrophil chemoattraction through the production of $\mathrm{C} 5 \mathrm{a}$ from the classical or alternative routes of action. As noted earlier, the work done by Killejian (1993) in our laboratory demonstrates that there is not a chemotactic response for neutrophils in the small intestine with adult worms although there is a stress response in the tissue which is demonstrated by the cellular production of the inducible form of heat shock protein 72 . The larvae which are deposited by the adults migrate by way of blood and lymph to the skeletal muscle. There is an increase in the number of muscle larvae over a period of time; the accumulation of larvae continues for approximately 19 days as the females continue depositing larvae. If C5a is produced, complement must attach to the invading skeletal muscle larvae for the classical or the alternative routes to be initiated. The alternative route may not be involved since there is no chemotactic response of neutrophils to the serum collected on day four of infection. For the classical route, IgM and IgG formed in response to the adult worms could be associated with a surface complement response; this is unlikely since the adult worms do not attract neutrophils to the infected mucosae. Complement $\mathrm{C} 5 \mathrm{a}$ is known to be chemoattractive for both neutrophils and monocytes, but in Prulhiere's work monocytes were not found in the cellular infiltrate surrounding the larvae in skeletal muscle. Therefore the involvement of $\mathrm{C5a}$ in the recruitment of neutrophils to the skeletal muscle infected with $T$. spiralis larvae is unlikely.

Numerous reports indicate that inflammation results when an organism gains access to a tissue (Jangles and Hugli, 1994, Prulhiere, 1994, Crabtree et al, 1995). We 
recognize that chemoattractants are available to assist neutrophils in their migration to sites of pathogenic activity (Shupe and Stewart, 1991, Crabtree et al, 1995). The term "chemokine" has just recently been accepted in the literature of biologists and biochemists (Miller and Krangel, 1992, Bagglioni 1993, Kunkel et al, 1994). The members of the CX-C family of chemokines, especially IL-8, appear to be the strongest and most specific chemoattractants for neutrophils known (Persson et al, 1993, Thomsen et al, 1991, Strom and Thomsen, 1990).

The value of inflammation as it relates to the well being of the host is a broad topic to evaluate. Although the inflammatory process has evolved to help rid the host organism of pathogens such as bacteria, foreign matter, and parasites, principally by the neutrophilic release of biologically active compounds such as elastase and collagenase and the generation of cytotoxic oxygen radicals; frequently the inflammatory system causes pathology in the host organism (Palmblad, 1984, Rizzo et al, 1992, Garner et al, 1994, Mitsuyama et al, 1994, Bittleman and Casale, 1994). Under optimal conditions the inflammatory process is in a delicate balance that allows containment or elimination of the foreign element with little damage to the host.

Although it's tempting to associate the in vitro chemotactic activity of neutrophils in response to serum components with the ability of the serum components to elicit this response in vivo, it is important to note that other factors may influence the mobilization of neutrophils to a site of pathogenic activity, and that generally it is not a single cytokine that is produced at the site. There are many factors and responses that may influence both the nature and magnitude of the neutrophil response in vivo. The extracellular matrix can 
bind cytokines which changes the availability to effector cells and can localize or change the duration of effect (Lortat-Jacob and Grimaud, 1994). The numbers of neutrophils present in the body and their responsiveness to chemokines can vary and be modified (Laterveer et al, 1995). There are vascular responses which can potentially alter blood flow and cell delivery. There are soluble adhesion proteins in the blood that may serve to limit the extravasation of neutrophils (Gamble et al, 1990). Changes in endothelial cells can influence vasopermeability and neutrophil adherence to vessel walls (Kunkel et al, 1994, Springer, 1992). There are also other cytokines and inflammatory mediators that augment or suppress the neutrophil's activity in a number of ways; in many cases it is clear that one cytokine not only acts in collaboration with another, but can induce the production of other cytokines or the same cytokine itself in an autocrine fashion, thereby amplifying the inflammatory process (Palmblad, 1984, Carlos and Harlan, 1994, Bittleman and Casale, 1994). In summation, the mobilization of neutrophils to a site of pathogenic activity involves a complex set of events subject to positive and negative regulation at a number of different steps. It is the cumulative effect of all these events that dictates the nature and amplitude of the neutrophil response at a site of pathogenic activity.

In the case of T.spiralis infection the inflammatory process appears to be modulated. Although the neutrophils are attracted to the site of larval invasion in the skeletal muscle, the inflammatory process does not proceed to the point of tissue damage to the host. Prulhiere (1994) observed that the infected muscle did not have a granulomatous appearance and there were no signs of tissue destruction such as abscess. Although the host defenses are unable to eliminate the parasite, the inflammation resolves 
and the parasite is maintained in the nurse cell for the life of the host. The resolution of inflammation may be the result of the host having "walled off" the parasite in the cyst, or more likely because the parasite remains metabolically active within the cyst which indicates it is not "walled off", the resolution of inflammation may be the result of parasite modulation of the host environment.

For parasite survival, it is essential that the host not be compromised too much. The T.spiralis larvae may have some way of modulating the inflammation so that its continued presence does not continue to elicit the inflammatory process; secretory/excretory proteins of the larva are implicated in this possibility (Gold et al, 1990, Lee et al, 1990), possibly in a manner similar to that in which the soluble GMP-140 molecule prevents neutrophil adhesion to endothelium and thereby limits inflammation (Gamble et al, 1990). Though the myositosis that occurs after larvae enter the muscle tissue does not eliminate the parasite or cause tissue damage, the neutrophils do initially attract to the site, so there must be some use for them to the parasite. Possibly the elastases and collagenases released by the neutrophils are responsible for the creation of the cyst and capillary rete that then provide nourishment, waste removal and protection for the larva during its stay (Baruch and Despommier, 1991). Possibly, these or other neutrophil products are necessary for the extensive morphological changes that take place in the myocyte as it becomes the nurse cell (Jasmer, 1990). Much more research is required to further elucidate the $T$.spiralis/host immune system interactions.

Making this situation more intriguing is the existence of other Trichinella species (there are currently thought to be eight) whose interactions with the host vary. Infection 
by Trichinella pseudospiralis in the mouse has been shown to be accompanied by much lower levels of enteritis and myositosis than those seen in mice infected with $T$. spiralis (Stewart et al, 1982). Recently Prulhiere (1994) compared the inflammatory response to T.spiralis, T.pseudospiralis, and T.sp.3. He found that the response varied considerably among the three species: The neutrophil accumulation was very heavy in the later stages of T.spiralis infection, mild in T.sp.3, and nonexistent in T.pseudospiralis. The timing of the appearance of neutrophils in the tissue was closely associated with the formation of the cyst in T.spiralis, and T.sp.3. T.pseudospiralis infection does not involve cyst formation. These results indicate that the organism is involved in modification of the inflammatory process and that the inflammatory process is involved in the morphology of the cyst formation.

It would be informative to repeat the experimental paradigm which has been employed in the current work, to study the chemotactic potential of sera of the various strains of $T$. Spiralis for neutrophils over the course of the infection to determine differences and correlate the histologic appearance of the infected tissue. Bruschi et al (1990) examined the sera from human beings infected during a T.sp.3 outbreak and found that the sera from infected individuals inhibited the chemotaxis of normal neutrophils. Another group studying T.spiralis and T.pseudospiralis (Shupe and Stewart, 1991) found the neutrophils from mice infected with T.pseudospiralis to be hyperchemotactic to zymosan-activated mouse serum compared with neutrophils isolated from mice infected with T.spiralis. They also found that extracts from T.pseudospiralis larva inhibited the chemotaxis of neutrophils from uninfected mice. Although these studies did not study the 
responses over the course of the infection, the results are intriguing and suggest that there is much to be learned about immune system modulation from T.spiralis and other

Trichinella species. 


\section{LITTERATURE CITED}

Asghar, S.S. 1995. Biology of Disease: membrane regulators of complement activation and their aberrant expression in disease. Laboratory Investigation 72(3): 254-271.

Baggiolini, M. 1993. Chemotactic and inflammatory cytokines--CXC and CC proteins. Advances in Experimental Medicine and Biology 351: 1-11.

Baruch, A.M. and Despommier, D.D. 1991. Blood vessels in Trichinella spiralis infections: a study using vascular casts. Journal of Parasitology 77(1): 99-103.

Bittleman, D.B. and Casale, T.B. 1994. Allergic Models and Cytokines. American Journal of Respiratory Critical Care Medicine 150: S72-S76.

Brennan, F.M., Zachariae, C.O.C., Chantry, D.,Larsen, C.G., Turner, M., Maini, R.N., Matsushima, K. and Feldman, M. 1990. Detection of interleukin 8 biological activity in synovial fluids from patients with rheumatoid arthritis and production of interleukin $8 \mathrm{mRNA}$ by isolated synovial cells. European Journal of Immunology 20: 2141-2151.

Bruschi, F., Solfanelli, S., and Binaghi, R.A. 1992. Trichinella spiralis: modifications of the cuticle of the newborn larva during passage through the lung. Experimental Parasitology 75(1): 1-9.

Carlos, T.M. and Harlan, J.M. 1994. Leukocyte-edothelial adhesion molecules. Blood 84(7): 2068-2101.

Crabtree, J.E., Covacci, A., Farmery, S.M., Xiang, Z., Tompkins, D.S., Perry, S., Lindley, I.J.D. and Rappuoli, R. 1995. Helicobacter pylori induced interleukin-8 expression in gastric epithelial cells is associated with CagA positive phenotype. Journal of Clinical Pathology 48: 41-45. 
Despommier, D.D., Sukhdeo, M. and Meerovitch, E. 1978. Trichinella spiralis: site selection by the larva during the enteral phase of infection in mice. Experimental Parasitology 44(2): 209-215.

Despommir, D.D., Gold, A.M., Buck, S.W., Capo, V. and Silberstein, D. 1990. Trichinella spiralis: secreted antigen of the infective L1 larva localizes to the cytoplasm and nucleoplasm of infected host cells. Experimental Parasitology 71(1): 27-38

Djeu, J.Y., Matsushima, K., Oppenheim, J.J., Shiotsuki, K. and Blanchard, D.K. 1990. Functional activation of human neutrophils by recombinat monocyte-derived neutrophil chemotactic factor/IL-8. Journal of Immunology 144: 2205-2210.

Falk, W., Goodwin, R.H.,Jr. and Leonard, E.J. 1980. A 48-well micro chemotaxis assembly for rapid and accurate measurement of leukocyte migration. Journal of Immunological Methods 33: 239-247.

Fontan, P.A., Amura, C.R., Garcia, C.R., Cerquetti, M.C. and Sordelli, D.O. 1992. Preliminary characterization of Pseudomona aeruginosa peptide chemoactins for polymorphonuclear leukocytes. Infectious Immunology 60: 2465-2469.

Frevert, C.W., Huang, S., Danaee, H., Paulauskis, J.D. and Kobzik, L. 1995. Functional characterization of the rat chemokine $\mathrm{KC}$ and its importance in neutrophil recruitment in a rat model of pulmonary inflammation. Journal of Immunology 154(1): $335-344$.

Furie, M.B. and McHugh, D.D. 1989. Migration of neutrophils across endothelial monolayers is stimulated by treatment of the monolayers with IL-1 or tumor necrosis factor-alpha. Journal of Immunology 143: 3309-3315.

Gallin, J.I. 1981. Abnormal phagocyte chemotaxis: pathophysiology, clinical manifestations, and management of patients. Reviews of Infectious Disease 3(6): 1196-1220.

Gallin, J.I. 1985. Neutrophil specific granule deficiency. Annual Review of Medicine 36: 263-274.

Gamble, J.R., Skinner, M.P., Berndt, M.C. and Vadas, M.A. 1990. Prevention of activated neutrophil adhesion to endothelium by soluble adhesion protein MP140. Science 249: 414-417. 
Garner, W.L., Rodriguez, J.L., Miller, C.G., Till, G.O., Rees, R.S., Smith, D.J. and Remick, D.G. 1994. Acute skin injury releases neutrophil chemoattractants. Surgery 116:42-48.

Goetzl, E.J. and Pickett, W.C. 1980. The human PMN leukocyte chemotactic activity of complex hydroxy-eicosatetraenoic acids (HETEs). Journal of Immunology 125(4): 1789-91.

Gold, A.M., Despommier, D.D. and Buck, S.W. 1990. Partial characterization of two antigens secreted by L1 larvae of Trichinella spiralis. Molecular and Biochemical Parasitology 41(2): 187-196.

Haribabu, B. and Snyderman, R. 1993. Identification of additional members of human G-protein-coupled receptor kinase multigene family. Proceedings of the National Academy of Sciences of the United States 90(20): 9398-9402.

Harley, J.P. and Galliccho, V. 1971. Trichinella spiralis: migration of the larvae in the rat. Experimental Parasitology 30: 11-21.

Harvath, L. 1991. Neutrophil chemotactic factors. Experentia Supplementum 59: 35-52.

Humes, A.G. and Akers, R.P. 1952. Vascular changes in the cheek pouch of the golden hamster during infection with Trichinella spiralis larvae. Anatomical Record 114: 103-113.

Hwang, S.B. 1990. Specific receptors of platelet-activating factor, receptor heterogeneity, and signal transduction mechanisms. Journal of Lipid Mediators 2(3-4): 123-158.

Jangles, M.A. and Hugli, T.E. 1994. Mechanisms and mediators of neutrophilic leukocytosis. Immunopharmacology 28(1): 1-18.

Jasmer, D.P. 1990. Trichinella spiralis: altered expression of muscle proteins in trichinosis. Experimental Parasitology 70(4): 452-465.

Kazacos, K.R., Little, A.S., Rohe, F.J., Wade, W.F. and Gaafar, S.N. 1986. A tongue biopsy technique for the detection of trichinosis in swine. Veterinary Parasitology 19: $151-156$. 
Kelner, G.S., Kennedy, J., Bacon, K.B., Kleyensteuber, S., Largaespada, D.A., Jenkins, N.A., Copeland, N.G., Bazan, J.F., Moore, K.W., Schall, T.J. and Zlotnik, A. 1994. Lymphotactin: acytokine that represents a new class of chemokine. Science 266: 1395-1399.

Kilejian, L.A. 1993. The influence of Trichinella spiralis infection on heat shock protein 72 production in the MRL++ mouse intestinal cells. Thesis. Portland State University.

Kunkel, S.L., Lukacs, N.W. and Strieter, R.M. 1994. The role of interlukin-8 in the infectious process. Annals of the New York Academy of Science 730: 134-143.

Laterveer, L., Lindley, I.J.D., Hamilton, M.S., Willemze, R. and Fibbe, W.E. 1995. Interleukin-8 induces rapid mobilization of hemapoietic stem cells with radioprotective capacity and long-term myelolymphoid repopulating ability. Blood 85(8): 2269-2275.

Lee, D.L., Ko, R.C., Yi, X.Y. and Yeung, M.H. 1991. Trichinella spiralis: antigentic epitopes from stichocytes detected in the heterotrophic nuclei and cytoplasm of the parasitized muscle fibre (nurse cell) of the host. Parasitology 102(1): 117-123.

Livingston, D.H., Appel, S.H., Sonnefeld, G., and Malangoni, M.A. 1989. The effect of tumor necrosis factor-alpha and interferon-gamma on neutrophil function. Journal of Surgery Research 46: 322-326.

Lorat-Jacob, H. and Grimaud, J.A. 1994. The extracellular matrix: from supporting tissue to regulation of cytokines. Pathologie Biologie 42(6): 612-620.

Matsushima, K. and Oppenheim, J.J. 1989. Interleuken 8 and MCAF: novel inflammatory cytokines inducible by IL 1 and TNF. Cytokine 1: 2-13.

Michel, L., Mencia-Huerta, J-M., Benveniste, J. and Dubertret, L. 1987. Biologic properties of LTB4 and paf-acether in vivo in human skin. Journal of Investigative Dermatology 88: 675-681.

Miller, M.D. and Krangel, M.S. 1992. Biology and biochemistry of the chemokines: A family of chemotactic and inflammatory cytokines. Critical Reviews in Immunology 12(1,2): 17-46. 
Mitsuyama, K., Toyonaga, A., Sasaki, E., Watanabe, K., Tateishi, H., Ninshiyama, T., Saiki, T., Ikeda, H., Tsuruta, O. and Tanikawa, K. 1994. IL-8 as an important chemoattractant for neutrophils in ulcerative colitis and Chron's disease. Clinical and Experimental Immunology 96(3): 432-436.

Newman, I., and Wilkinson, P.C. 1989. Chemotactic activity of lymphotoxin and tumor necrosis factor alpha for human neutrophils. Immunology 66: 318-320.

Pagenstecher, H.A. 1865. Die Trichinen. Engelmanns, Leipzig. 116 p.

Palmblad, J. 1984. The role of granulocytes in inflammation. Scandinavian Journal of Rheumatology 13: 163-172.

Persson, K., Larsson, I. and Hallen-Sandgren, C. 1993. Effects of certain inflammatory mediators on bovine neutrophil migration in vivo and in vitro. Veterinary Immunology and Immunopathology 37(2): 99-112.

Prulhiere, J.D. 1994. Comparison of neutrophil migration in the mouse in response to infection with three species of Trichinella. Thesis, Portland State University.

Ribeiro, R.A., Flores, C.A., Cunha, F.Q. and Ferreira, S.H. 1991. IL-8 causes in vivo neutrophil migration by a cell-dependent mechanism. Immunology 73: 472-477.

Richter, J., Andersson, T., and Olsson, I. 1989. Effect of colony-stimulating factor and granulocy/macrophage colony-stimulating factor on neutrophil degranulation. Journal of Immunology 142: 3199-3205.

Rizzo, R.S., Witkon, K., Chen, A.I., Hadjiyane, C., Weinstein, M.I. and Pellecchia, C. 1992. Interleukin-8 and neutrophil markers in colonic mucosa from patients with ulcerative colitis. American Journal of Gastroenterology 87(10): 1447-1452.

Rosales, C., and Juliano, R.L. 1995. Signal transduction by cell adhesion receptors in leukocytes. Journal of Leukocyte Biology 57: 189-198.

Samanta, A.K., Oppenheim, J.J., and Matsushima, K. 1989. Identification and characterization of a specific receptor for monocyte-derived neutrophil chemotactic factor (MDNCF) on human neutrophils. Journal of Experimental Medicine 169: 1185-1189. 
Shiratori, Y., Takada, H., Hai, K., Kiriyama, H., Mawet, E., Komatsu, Y., Niwa, Y., Matsumura, M., Shiina, S. and Kawase, T. 1994. Effect of anti-allergic agents on chemotaxis of neutrophils by stimulation of chemotactic factor released from hepatocytes exposed to ethanol. Digestive Diseases and Sciences 39(7): 1569-1575.

Shupe, K. and Stewart, G.L. 1991. Stimulated chemotactic response in neutrophils from Trichinella pseudospiralis-infected mice and the neutrophilotactic potential of trichinella extracts. International Journal for Parasitology 21(6): 625-630.

Siciliano, S.J., Rollins, T.E. and Springer, M.S. 1990. The interaction between the C5a receptor and $\mathrm{Gi}$ in both the membrane-bound and detergent-solubilized states. Journal of Biological Chemistry 265(32): 19568-74.

Smith, W.B., Gamble, J.R., Clark-Lewis, I. and Vadas, M.A. 1991. Interleukin-8 induces neutrophil transendothelial migration. Immunology 72: 65-71.

Smith, W.B., Gamble, J.R., Clark-Lewis, I. and Vadas, M.A. 1993. Chemotactic desensitization of neutrophils demonstrates interleukin-8 (IL-8)-depenent and IL-8-independent mechanisms of transmigration through cytokine-activated endothelium. Immunology 78: 491-497.

Snyderman, R., Altman, L.C., Hausman, M.S., and Mergenhagen, S.E. 1972. Human mononuclear leukocyte chemotaxis: A quantitative assay for humoral and cellular chemotactic factors. Journal of Immunology 108(3):857-860.

Springer, T.A. 1994. Traffic signals for lymphocyte recirculation and leukocyte emigration: the multistep paradigm. Cell 76: 301-314.

Stewart, G.L., Charniga, L., and Boley, R.B. 1982. Myositosis in mouse trichinellosis. Journal of Parasitology 68(4): 730-732.

Strom, H. and Thomsen, M.K. 1990. Effects of proinflammatory mediators on canine neutrophil chemotaxis and aggregation. Veterinary Immunology and Immunopathology 25: 209-217.

Thomsen, M.K., Larsen, C.G., Thomsen, H.K., Kirstein, D., Skak-Nielsen, T., Ahnfelt-Ronne, I. and Thestrup-Pedersen, K. 1991. Recombinant human interleukin- 8 is a potent activator of canine neutrophil aggregation, migration, and leukotriene B4 biosynthesis. Journal of Investigative Dermatology 96: 260-266. 
Tsuchiya, I., Kasahara, T., Yamashita, K., Ko, Y.C., Kamazawa, K., Matsushima, K. and Mukaida, N. 1993. Induction of inflammatory cytokines in the pleural effusion of cancer patients after the administration of an immunomodulator, OK-432: role of IL-8 for neutrophil infiltration. Cytokine 5(6): 595-603.

Wang, C.H., and Bell, R.G. 1986. Trichinella spiralis: vascular recirculation and organ retention of newborn larvae in rats. Experimental Parasitology 62(3): 430-441.

Xu, L., Kelvin, D.J., Ye, G.Q., Taub, D.D., Ben-Baruch, A., Oppenheim, J.J. and Wang, J.M. 1995. Modulation of $\mathrm{IL-8}$ receptor expression on purified human $\mathrm{T}$ lymphocytes is associated with changed chemotactic responses to IL-8. Journal of Leukocyte Biology 57: 335-342.

Yano, S., Sone, S., Nishioka, Y., Mukaida, N., Matsushima, K. and Ogura, T. 1995. Differential effects of anti-inflammatory cytokines (IL-4, IL-10 and $\mathrm{IL}-13$ ) on tumoricidal and chemotactic properties of human monocytes induced by monocyte chemotactic and activating factor. Journal of Leukocyte Biology 57: 303-309.

Zeillemaker, A.M., Mul, F.P.J., VanPapendrecht, A.A.G.M.H., Kuijpers, T.W., Roos, D., Leguit, P. and Verbrugh, H.A. 1995. Polarized secretion of interleukin-8 by human mesothelial cells: a role in neutrophil migration. Immunology 84: 227-232. 